\title{
Congenital syphilis in the Municipality of Imperatriz, Maranhão State: Epidemiological characterization of a decade
}

\section{Kecya Patricia Costa Macedo ${ }^{1}$, Matheus Costa Silva1, Jéssica Larissa Sousa Vaz ${ }^{2}$, Soliane Cristina Rodrigues Costa ${ }^{2}$, Roseane Mara Cardoso Lima Verde ${ }^{3}$, Matheus Hipólito do Nascimento ${ }^{4}$, Leonardo Ferreira Soares ${ }^{5}$ and Evaldo Hipólito de Oliveira ${ }^{2}$}

\author{
${ }^{1}$ College of Santo Agostinho. Av. Valter Alencar, 665. São Pedro. Teresina-PI. Brazil \\ (CEP 64049-550). \\ ${ }^{2}$ Federal University of Piauí. Center for Health Sciences. Minister Petrônio Portella \\ University Campus. Ininga. Teresina-PI. Brazil (CEP64049-550). \\ ${ }^{3}$ Graduate Program in Biomedical Engineering - Brasil University. São Paulo-SP, \\ Brazil (CEP 08230-030). \\ ${ }^{4}$ College of Dentistry. Unieuro University Center. Setor de Clubes Esportivos Sul, \\ Trecho 0, Conjunto 05. Asa Sul. Brasília-DF (CEP 70200-001). \\ ${ }^{5}$ Centre of Biological, Social and Applied Sciences. State University of Paraíba. \\ Baraúnas Street, 351. Cristo Redentor. João Pessoa-PB. Brazil. (CEP 58429-500).
}

\begin{abstract}
Congenital syphilis, caused by the bacterium Treponema pallidum, is one of most prevalent diseases in Brazil. The diagnosis is made through treponemal and non-treponemal tests during prenatal care, in which reagent results are necessary to initiate treatment in order to avoid fetal contamination, miscarriage, prematurity, neurological sequelae, among other fetal and maternal complications. The objective of this study was to investigate the prevalence of congenital syphilis to describe the epidemiological profile based on cases reported in the Municipality of Imperatriz, Maranhão State, Brazil. This is an exploratory, retrospective, descriptive and quantitative study developed between 2010 and 2017. The results obtained in the study reveal that in the period from 2010 to 2017, an accumulated total of 2,507 cases of congenital syphilis were reported in the state of Maranhão, and 514 cases were registered in Imperatriz, representing $20.50 \%$ of the total. The study demonstrated the need for effective measures to combat not only the infection of mothers, but also of partners; some of these diagnoses were only identified during or after childbirth/curettage. The lack of previous investigation or lack of adequate treatment during the gestation leading to maternal and fetal risk was evident.
\end{abstract}

Keywords: Pregnancy; Vertical transmission; Congenital syphilis; Epidemiology.
Received

August 8, 2018

Accepted

August 29, 2018

Released

August 31, 2018

Full Text Article

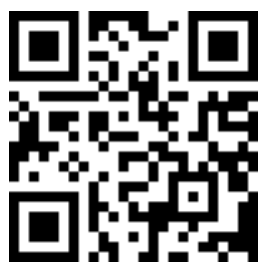

ORCID

() 0000-0003-4170-6301 Kecya Patricia Costa Macedo

๑ 0000-0002-7589-2117 Matheus Costa Silva 


\section{Introduction}

At present, it is estimated that there are about 1.8 million pregnant women in the world infected with syphilis and less than $10.0 \%$ are diagnosed and treated. The control of syphilis in Brazil is part of the goals of the Pact for Health, emphasizing the need for screening all pregnant women during prenatal care and providing timely treatment in order to contain the infection (Lafeta et al., 2016).

Non-realization of prenatal care has many consequences for maternal and fetal health. Data show that pregnant women who participate and perform prenatal care present fewer complications during gestation and postnatal life, and appropriate intrauterine development (Rasia and Albernaz, 2008), revealing a strong connection between prenatal care and healthy growth of the infant (Paris et al., 2013). Thus, the lack of care often leads to irreparable risks to mother and fetus (Anversa et al., 2012).

Limited access to health services, teenage pregnancy, the presence of other STDs and the use of illicit drugs such as crack or cocaine are some of the risk factors that are related to congenital

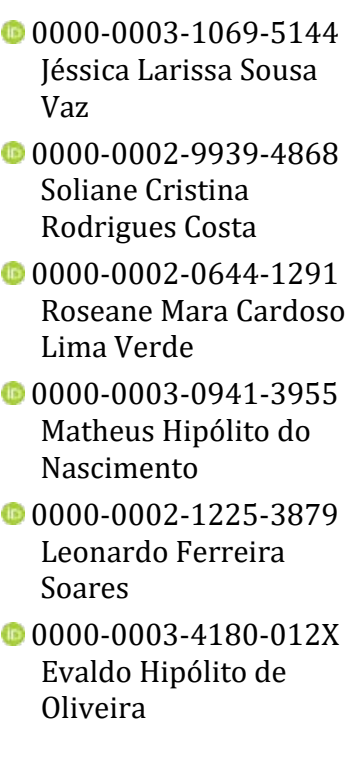

syphilis infection (Machado and Terra, 2015).

Congenital syphilis is one of the diseases that have preventable maternal and fetal mortality because efficient diagnosis and treatment during pregnancy is possible, interrupting the transmission from mother to child (WHO, 2008). Studies have shown that countries that have managed to control congenital syphilis had quality prenatal care as basis, this monitoring still has another benefit: the expenses with healthy newborns are lower than those with children infected with Treponema pallidum (Lopes, 2015).

Treponema pallidum is a long, thin, spiral-shaped, gram-negative bacillus from the spirochete group that causes syphilis, a sexually transmitted infectious disease that is vertically transmitted from woman to fetus during pregnancy (Belda Junior et al., 2009) and may result in miscarriage, late fetal losses, neonatal death, sick or asymptomatic neonates, with possible progress to severe problems if untreated (Domigues et al., 2014).

Congenital syphilis occurs when T. pallidum crosses the placental barrier at any stage of gestation or at birth where the baby comes in contact with the 
mother's fluids (Pinheiro, 2011). Maternal inoculation in most cases leads to miscarriage, stillbirth or poor fetal formation, which is divided into two stages: early and late. Early infection occurs in up to two years of life and causes symptoms such as exatema, hepatosplenomegaly, erythroblastosis, and osteochondritis, among others. Late infection occurs after two years of life and causes bone, ocular and brain injuries, gummas and Hutchinson's triads (Kalinin et al., 2016).

Treponemal and non-treponemal tests are used as screening tests for diagnosis of syphilis. The validated treponemal tests for confirmation of infection include the FTA-ABS (treponemal antibody absorption test) and TPHA (Treponema pallidum hemaglutination assay). In turn, nontreponemal tests, which are posttreatment tests for diagnosis, include the VDRL (Venereal Disease Research Laboratory), and RPR (rapid plasma reagin) (Damasceno, 2014).

Not only pregnant women but also partners should adhere to treatment of congenital syphilis (Silva, 2016). Both should start treatment to avoid that the fetus be infected, because when this pathology affects the fetus, it can bring severe complications for the newborn (Domingues and Leal, 2016).

In 2005, through Decree No. 33, July 14, 2005, the Ministry of Health included congenital syphilis in the national list of diseases of compulsory notification so as to make it to be considered a public health problem. Thus, all cases detected should be declared in the National Disease Notification System (SINAN) (São Paulo, 2008).

Therefore, the present study aimed to establish the prevalence of congenital syphilis, tracing an epidemiological profile based on cases reported in the Municipality of
Imperatriz, Maranhão State, Brazil.

\section{Methodology}

This is an exploratory, retrospective, descriptive, and quantitative study carried out in the municipality of Imperatriz in the state of Maranhão from 2010 to 2017. Data were collected from the DataSUS website, the National Disease Notification System (SINAN) and the Information System on Live Births (SINASC). The information is in the section "health information" (TABNET), in the option "epidemiology and morbidities".

The bibliographic research was carried out in the databases of the Scientific Electronic Library Online (SCIELO), in the Latin American and Caribbean Literature in Health Sciences (LILACS) and through the VHL Research Portal, only between 2008 and 2018. The following descriptors were used: congenital syphilis, congenital syphilis in Maranhão, notification of injuries/ diseases, epidemiological profile.

The following variables were studied: year of diagnosis; municipality where the notification was made; age and sex of the child; mother's level of education; prenatal care; maternal syphilis; partner's treatment; final classification; and clinical evolution. The calculation of the incidence rate of congenital syphilis was obtained by dividing the number of cases in a given year by the number of live births in the same year and multiplying the result by one thousand; this way the number of cases of congenital syphilis per 1000 live births was obtained.

The health map, tables and graphs were calculated through absolute and percentage frequencies, processed in the softwares Microsoft Office and Microsoft Excel 2016 and Tab for Windows (TabWin) version 4.14.

\section{Results}


In the period from 2010 to 2017, an accumulated total of 2,507 cases of congenital syphilis were recorded in the state of Maranhão and listed in tables of the National Disease Notification System (SINAN). In this period, of the total of 217 municipalities, only 63 reported cases of this pathology. The highest incidence of cases in the state was found in the capital
São Luís, with 1,224 cases, followed by Imperatriz, the city studied in the present paper, with 514 cases, representing $20.50 \%$ of the total. The municipality of Timon was the third position in the ranking of notifications (274 cases), as shown in the health map (Figure 1).

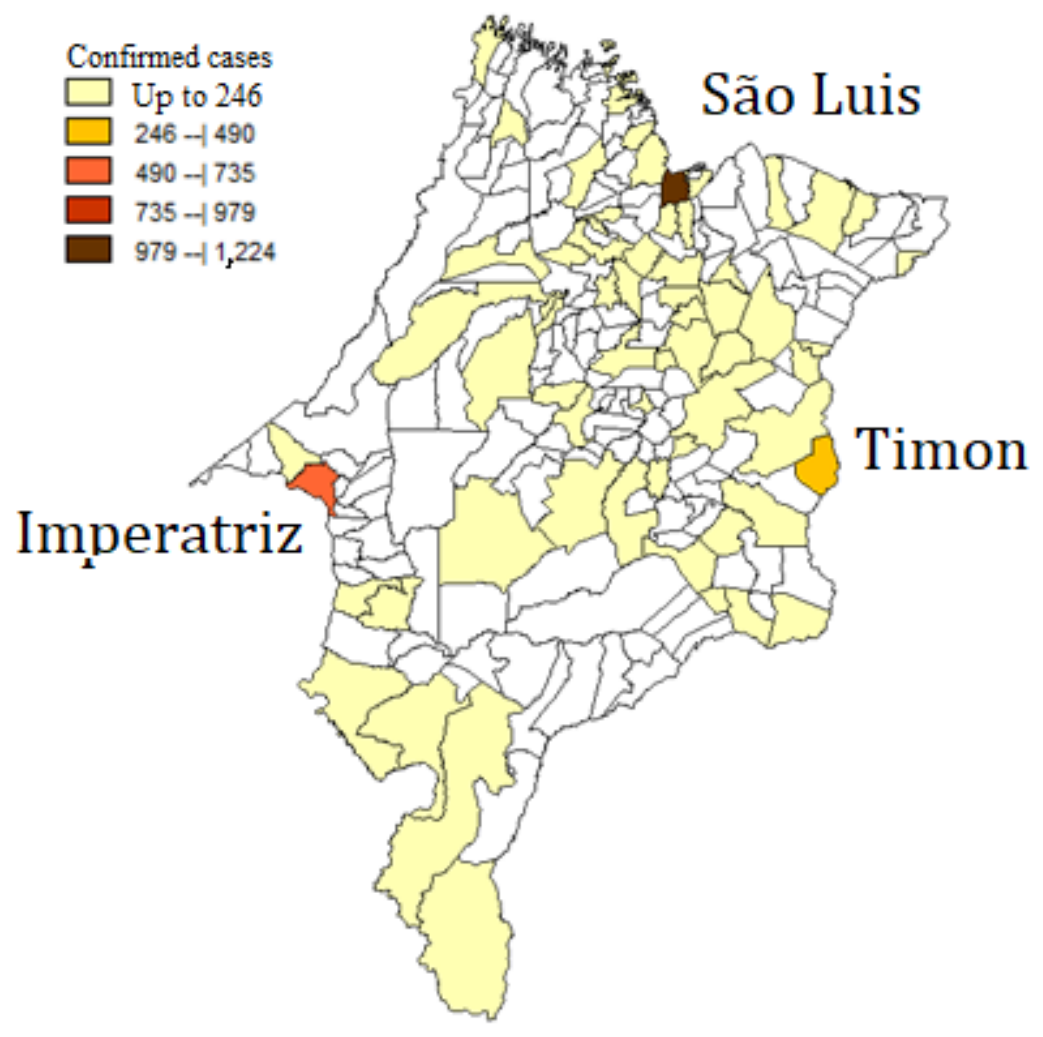

Figure 1. Geographic distribution of confirmed cases of congenital syphilis reported in the Maranhão State, from 2010 to 2017. Source: Ministry of Health/SVS, National Disease Notification System - Sinan Net, 2018.

Figure 1 shows the distribution of confirmed cases of congenital syphilis between the years 2010 and 2017 in the state of Maranhão, specifically in the city of Imperatriz. It can be observed that there was no steady upward trend or a steady decline; there is always a fluctuation in the time interval analyzed. The most prevalent interval was related to the year 2016, with 138 cases, representing $26.84 \%$ of the total. The lowest prevalence was observed in 2017, with only 24 cases. In relation to the incidence rate of congenital syphilis, a rate of 8.04 cases per 1000 live births was observed in 2011, decreasing to 3.81 cases in 2015 and experiencing an exponential increase to 14.10 cases/ 1000 live births in 2016. 


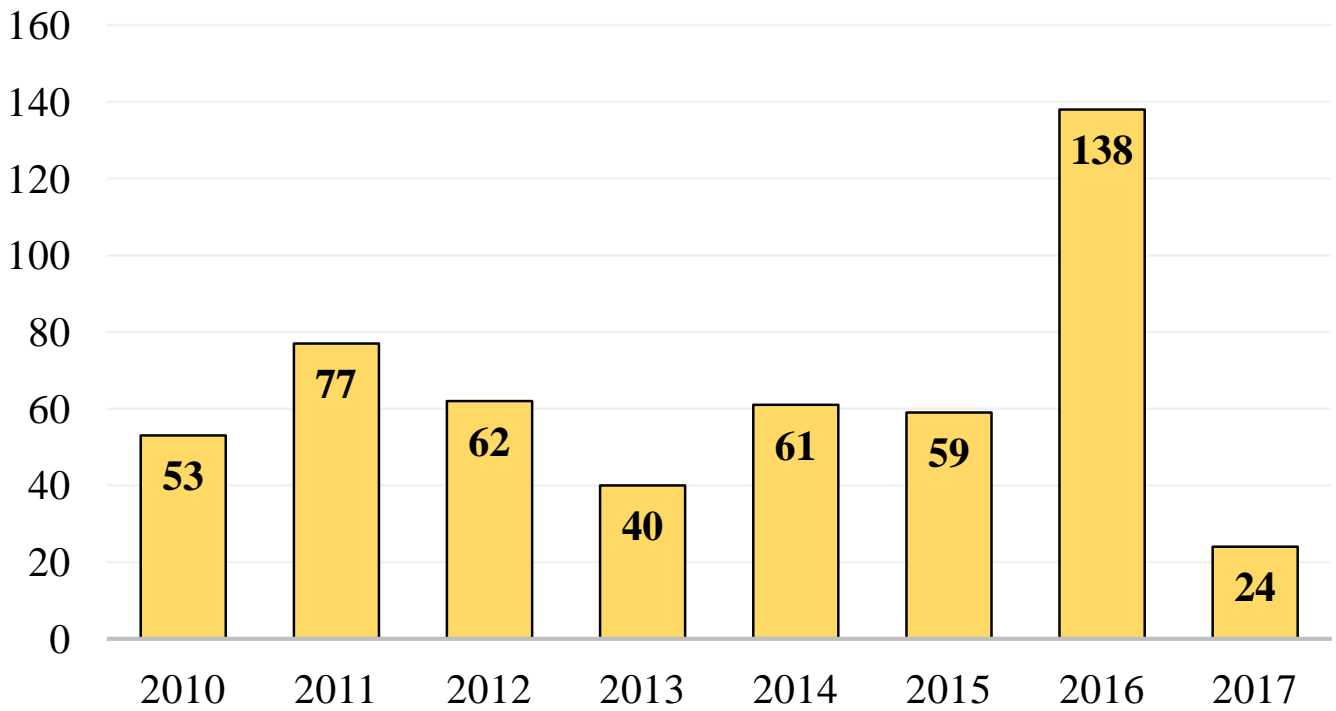

Figura 2. Total number of confirmed cases of congenital syphilis in the second year of diagnosis in the municipality of Imperatriz-MA from 2010 to 2017. Source: Ministry of Health/SVS - National Disease Notification System - Sinan Net, 2018.

Among the reported cases, 233 cases $(98.72 \%)$ were diagnosed in infants up to six days old; 1 case $(0.42 \%)$ in a baby aged 7 to 27 days; and 2 cases (0.84\%). in children aged 28 days to 1 year. Regarding sex, 47.03\% (111 cases) cases were male children, $49.15 \%$ (227 cases) were female children and in
$3.81 \%$ of the records this information was ignored.

According to Table 1, the majority of mothers in this period had studied up to the 5 th to 8 th grade, i.e. had incomplete middle school, and the lowest percentage was of mothers with complete higher education.

Table 1. Confirmed cases of congenital syphilis reported in the Municipality of Imperatriz, Maranhão State, according to level of education of mothers from 2010 to 2017.

\begin{tabular}{lcc}
\hline Schooling & $\mathrm{n}$ & $\%$ \\
\hline Ignored/blank space & 10 & 4.24 \\
Illiterate & 5 & 2.12 \\
$1^{\text {st to }} 4^{\text {th }}$ grade, incomplete ES & 8 & 3.39 \\
$1^{\text {st }}$ to $4^{\text {th }}$, complete ES & 6 & 2.54 \\
$5^{\text {th to }} 8^{\text {th }}$, incomplete MS & 91 & 38.56 \\
Complete MS & 31 & 13.14 \\
Incomplete HS & 31 & 13.14 \\
Complete HS & 50 & 21.19 \\
Incomplete HE & 3 & 1.27 \\
Complete HE & 1 & 0.42 \\
Not applicable & 0 & 0 \\
\hline Total & $\mathbf{2 3 6}$ & $\mathbf{1 0 0}$ \\
\hline
\end{tabular}


Legend: ES (Elementary School); MS (Middle School); HS (High School); HE (Higher Education). Source: Ministry of Health/SVS, National Disease Notification System - Sinan Net, 2018.

For most mothers, the diagnosis of maternal syphilis was found out during prenatal care, evidencing the importance of this service for the detection of nonconformities and for the health of the pregnant woman and the baby. However, a significant proportion of patients were diagnosed only during or after delivery/curettage.

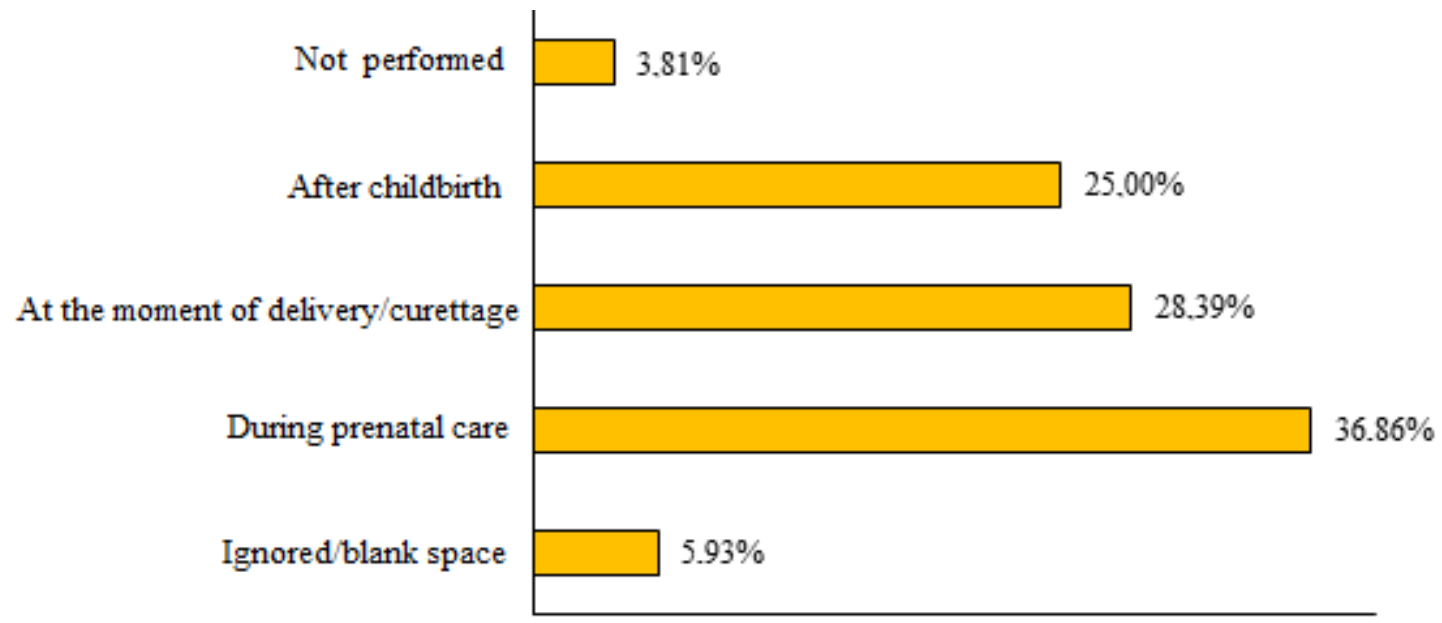

Figura 3. Confirmed cases of congenital syphilis in the municipality of Imperatriz-MA according to the diagnosis of maternal syphilis from 2010 to 2017. Source: Ministry of Health / SVS - National Disease Notification System- Sinan Net, 2018.

It was observed that there are no or few cases in which the pregnant women did not perform the prenatal follow-up, a behavior that persisted over the years from 2010 to 2017. According to Table 2, during this period, the prenatal follow-up was performed by $85.16 \%$ (201) of the mothers of children with congenital syphilis.

Table 2. Confirmed cases of congenital syphilis reported in Imperatriz-MA according to prenatal care from 2010 to 2017.

\begin{tabular}{lccccccc}
\hline & \multicolumn{2}{c}{$\begin{array}{c}\text { Ignored/blank } \\
\text { space }\end{array}$} & \multicolumn{2}{c}{ Yes } & \multicolumn{2}{c}{ No } & \multirow{2}{*}{ Total (n) } \\
\cline { 2 - 6 } & $\mathrm{n}$ & $\%$ & $\mathrm{n}$ & $\%$ & $\mathrm{n}$ & $\%$ & \\
\hline $\mathbf{2 0 1 0}$ & 0 & 0.00 & 29 & 14.43 & 2 & 8.33 & $\mathbf{3 1}$ \\
$\mathbf{2 0 1 1}$ & 0 & 0.00 & 33 & 16.42 & 7 & 29.17 & $\mathbf{4 0}$ \\
$\mathbf{2 0 1 2}$ & 0 & 0.00 & 18 & 8.96 & 3 & 12.50 & $\mathbf{2 1}$ \\
$\mathbf{2 0 1 3}$ & 1 & 9.09 & 15 & 7.46 & 1 & 4.17 & $\mathbf{1 7}$ \\
$\mathbf{2 0 1 4}$ & 0 & 0.00 & 23 & 11.44 & 0 & 0.00 & $\mathbf{2 3}$ \\
$\mathbf{2 0 1 5}$ & 3 & 27.27 & 14 & 6.97 & 3 & 12.50 & $\mathbf{2 0}$ \\
$\mathbf{2 0 1 6}$ & 3 & 27.27 & 60 & 29.85 & 6 & 25.00 & $\mathbf{6 9}$
\end{tabular}




\begin{tabular}{|c|c|c|c|c|c|c|}
\hline 4 & 36.36 & 9 & 4.48 & 2 & 8.33 & 15 \\
\hline 11 & & 201 & & 24 & & 236 \\
\hline
\end{tabular}

Source: Ministry of Health/SVS, National Disease Notification System - Sinan Net, 2018.

In all the analyzed years, it is evaluate aspects relevant to care observed that most of the partners did not do treatment along with the infected pregnant women, a behavior observed in $49.15 \%$ of the occurrences (116 cases). Moreover, it was noted that in $41.10 \%$ (97 cases) of the records, this information was ignored, making it difficult to interpret the data and policies.Only in 23 cases $(9.74 \%)$ the treatment of partners of the pregnant women was reported.

Only one death from congenital syphilis was recorded in the city of Imperatriz, in 2017 (Figure 4). In general, patients diagnosed with congenital syphilis remained alive.

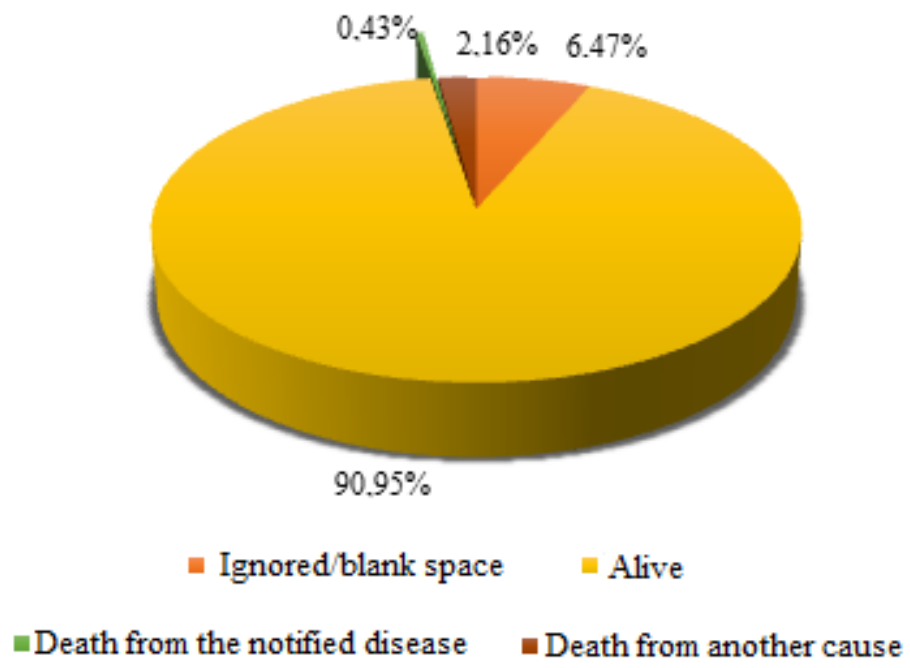

Figure 4. Evolution of confirmed cases of congenital syphilis reported in the municipality of Imperatriz-MA from 2010 to 2017. Source: Ministry of Health/SVS - National Disease Notification System - Sinan Net, 2018.

Regarding the final classification of the cases, it was observed that almost 224 cases (94.91\%) were considered early congenital syphilis; in 8 cases the information was ignored; and in 4 cases, it was discarded.

\section{Discussion}

In the period from 2010 to 2017, 514 cases of congenital syphilis were registered in Imperatriz. This data represent about $20.50 \%$ of the total number of cases reported in the state of
Maranhão, much higher than that established by the Pan American Health Organization (PAHO) and the National Program for the Eradication of Congenital Syphilis from the Ministry of Health, which is $1 / 1000$ live births.

The high incidence of cases in Imperatriz, Maranhão, can be related to the increase of notifications, analysis of cases, and may be a reflection on unsatisfactory actions to combat the infection in the municipality. Between 2010 and 2017, the lowest incidence was found in 2017, with only 24 cases, with 
an exponential increase to 138 cases in 2016, with unsteady trends along this period.

Prenatal care represents a safeguard of maternal and fetal wellbeing, promoting lower infection and mortality rates. Prenatal screening tests serve to track diseases, and among these, the test made in filter paper is an inexpensive, quick-to-perform test for infectious pathologies that are transmitted to the fetus during pregnancy and often incur irreversible risks. Tests should be performed since the first consultation, in the third trimester of pregnancy and at the moment of delivery, even if previous tests were performed (Almeida Filho and Moreira, 2017).

In order to prevent congenital syphilis, it is necessary to provide quality medical care, especially in places less favored by public resources, ensuring a rapid and quality screening of infectious diseases. Actions to raise awareness and early diagnosis are also needed, since, according to the data collected, the highest incidences of cases, are found among pregnant women with low schooling who were diagnosed during the gestational period. This demonstrates the effectiveness of the prenatal screening program and lack of prevention counseling (Schust et al., 2017), because it is known that cases of syphilis transmitted in the gestational period represent the highest rates of contagion (Santos and Leite, 2018).

The study also shows that among the cases of babies reported, the majority of them was diagnosed in the first six days of life (233 cases) and greater incidence was found among female children, among which only 1 death due to congenital syphilis was registered in the city of Imperatriz, in 2017.

The treatment of congenital syphilis during pregnancy is made with penicillin in most cases, a drug that has proven efficacy and when correctly and timely used, it results in smaller possibilities of aggravations and transmission, besides reaching the cure (Guinsburg et al., 2010).

In all the analyzed years, it was noticed that the majority of the partners did not adhere to treatment concomitantly with the infected pregnant women, a behavior observed in $49.15 \%$ of the occurrences (116 cases). This reveals that a larger portion of the pregnant women is in contact with Treponema pallidum, what is considered an important epidemiological data (Clemente el al., 2012). These data reflect previous knowledge that males are less concerned about health and have less contact with health services (Gomes et al., 2007).

The concomitant treatment of pregnant women and their partners prevents a new contamination. When treatment is done in a timely manner, the transmission to the fetus may not occur, minimizing the harmful effects of congenital syphilis. Among the sequels for the newborn are deafness, hepatomegaly, splenomegaly, lymphadenopathy, osteochondritis, periostitis and syphilitic osteomyelitis, as well as severe neurological problems, depending on each stage of contamination (DO PROGRAM, 2008).

Besides prenatal care, it is necessary to adopt other skilled control actions, such as the use of condoms, lower number of sexual partners, diagnosis and early treatment of partners, and family counseling (Mascarenhas et al., 2016).

\section{Conclusion}

The data collected and analyzed in Imperatriz, Maranhão State, Brazil, between 2010 and 2017, recorded 514 cases. This fact evidenced the need for effective measures to combat not only maternal infection but also the infected partner. Although the study showed that the number of episodes in which the pregnant women did not receive prenatal care is very few or nonexistent, the study also confirms that some of these 
pregnant women were only identified during or after delivery/curettage, highlighting the lack of diagnosis, or appropriate treatment during pregnancy. Such situation incurs risks for maternal and fetal health.

\section{Conflict of interest}

Authors declare that they have no conflict of interests.

\section{References}

Almeida Filho, A. C. S.; Moreira, R. C. R. Saberes de gestantes sobre a triagem prénatal em papel filtro: contribuição para prevenção de doenças e agravos. Anais Seminário de Iniciação Científica, n. 21, 2017. Available from: <http://periodicos. uefs.br/index.php/semic/article/view/2281 /1885>. Accessed on: Jun. 26, 2018.

Anversa, E. T.; Bastos, G. A.; Nunes, L. N.; Dal Pizzol, T. S. Qualidade do processo da assistência pré-natal: unidades básicas de saúde e unidades de Estratégia Saúde da Família em Município no Sul do Brasil. Cadernos de Saúde Pública, v. 28, p. 789800, 2012. https://doi.org/10.1590/S0102311X2012000400018

Belda Junior, W.; Shiratsu, R.; Pinto, V. Abordagem nas doenças sexualmente transmissíveis. Anais Brasileiros de Dermatologia, v. 84, no. 2, p. 151-159. 2009. https://doi.org/10.1590/S0365-05962009 000200008

Clemente, T. S.; Lima, M. M.; Barros, L. A.; França, A. M. B.; Bento, T. M. A. A importância do pré-natal como ferramenta na prevenção da sífilis congênita: revisão bibliográfica.

Caderno de Graduação, Ciências Biológicas e da Saúde Fits, v. 1, no.1, p. 33-42, 2012. Available from: <https://periodicos.set.edu.br/index.php/fit sbiosaude/article/view/455/188>. Accessed on: Jun. 26, 2018.

Damasceno, A. B.; Monteiro, D. L.; Rodrigues, L. B.; Barmpas, D. B. S.; Cerqueira, L. R.; Trajano, A. J. Sífilis na gravidez. Revista Hospital Universitário Pedro Ernesto, v. 13, no. 3, p. 88-94, 2014. https://doi.org/10.12957/rhupe.2014.12133 Domingues, R. M. S. M.; Szwarcwald, C. L.; Souza Junior, P. R. B.; Leal, M. D. C. Prevalence of syphilis in pregnancy and prenatal syphilis testing in Brazil: Birth in Brazil study. Revista de Saúde Pública, v. 48, no. 5, p. 766-774, 2014. https://doi.org/10.1590/ S0034-8910.2014048005114

Domingues, R. M. S. M.; Leal, M. C. Incidência de sífilis congênita e fatores associados à transmissão vertical da sífilis: dados do estudo Nascer no Brasil. Cadernos de Saúde Pública, v. 32, no. 6, e082415, 2016. https://doi.org/10.1590/0102-311X000 82415

Gomes, R.; Nascimento, E. F.; Araújo, F. C. Por que os homens buscam menos os serviços de saúde do que as mulheres? As explicações de homens com baixa escolaridade e homens com ensino superior. Cadernos de Saúde Pública, v. 23, no. 3, p. 565-574, 2007. https://doi.org/10.1590/S0102-311X2 007000300015

Guinsburg, R.; Santos, A. M. N. D. Critérios diagnósticos e tratamento da sífilis congênita. Rio de Janeiro: Sociedade Brasileira de Pediatria, 2010. (Documento Científico do Departamento de Neonatologia). Available from: <http://www.sbp.com.br/fileadmin/user_upl oad/2015/02/tratamento_sifilis.pdf $>$.

Accessed on: Jun. 26, 2018.

Kalinin, Y.; Passarelli Neto, A.; Passarelli, D. H. C. Sífilis: aspectos clínicos, transmissão, manifestações orais, diagnóstico e tratamento. Odonto, v. 23 , no. $45 / 46$, p. 6576, 2016. https://doi.org/10.15603/21761000/odonto.v23n45-46p65-76

Lafetá, K. R. G.; Martelli Júnior, H.; Silveira, M. F.; Paranaíba, L. M. R. Maternal and congenital syphilis, underreported and difficult to control. Revista Brasileira de Epidemiologia, v. 19, no. 1, p. 63-74, 2016. https://doi.org/10.1590/1980-54972016 00010006

Lopes, I. M. D. Epidemiologia de gestantes soropositivas para o Treponema pallidum e adesão ao acompanhamento dos recémnascidos. Aracaju: Universidade Tiradentes, 2015. (Dissertation). Available from: <https://mestrados.unit.br/wp-content/ uploads/sites/6/2011/05/EPIDEMIOLOGIADE-GESTANTES-SOROPOSITIVAS-PARA-OTREPONEMA-PALLIDUM-E-ADESÃO-AOACOMPANHAMENTO-DOS-RECÉMNASCIDOS.pdf>. Accessed on: Jun. 26, 2018. Machado, B. L.; Terra, M. R. A sífilis na gestação: uma problemática atual. Brasília: 
Ministério da Saúde, 2015. (Protocolo clínico e diretrizes terapêuticas para prevenção da transmissão vertical de HIV, sífilis e hepatites virais).

Mascarenhas, L. E. F.; Araújo, M.S.S.; Gramacho, R. C.C.V. Desafios no tratamento da sífilis gestacional. Salvador: Escola Bahiana de Medicina e Saúde Pública, 2016. Available from: <http://www7.bahiana.edu.br/jspui/handle /bahiana/735>. Accessed on: Jun. 26, 2018.

Paris, G. F.; Martins, P. M.; Pelloso, S. M. Qualidade da assistência pré-natal nos serviços públicos e privados. Revista Brasileira de Ginecologia e Obstetrícia, v. 35, no. $10, \quad$ p. 447-452, 2013. https://doi.org/10.1590/S0100-72032013 001000004

Pinheiro, V.A. O. Aspectos científicos, epidemiológicos, preventivos, diagnóstico e de tratamento relativos à sífilis e a sífilis congênita no Brasil: uma revisão bibliográfica. Lagoa Santa: Universidade Federal de Minas Gerais, 2011. (Monography). Available from: <https://www.nescon.medicina.ufmg.br/bibl ioteca/imagem/4756.pdf>. Accessed on: Jun. 26, 2018.

Rasia, I. C. R. B.; Albernaz, E. Atenção pré-natal na Cidade de Pelotas, Rio Grande do Sul, Brasil. Revista Brasileira de Saúde Materno Infantil, v. 8, no. 4, p. 401-410, 2008. https://doi.org/10.1590/S151938292008000400005
Santos, C. M.; Leite, D. S. Congenital syphilis in Marabá (State of Pará, Brazil): Epidemiological analysis of a decade. Brazilian Journal of Biological Sciences, v. $5, \quad$ n. $9, \quad$ p. 183-193, 2018. http://doi.org/10.21472/bjbs.050918

São Paulo. Secretaria de Estado da Saúde. Sífilis congênita e sífilis na gestação. Revista de Saúde Pública, v. 42, n. 4, p. 768-772, $2008 . \quad$ https://doi.org/10.1590/S003489102008000400026

Schust, A. B. H.; Suezawa, Y. D. S.; Elias, P. G.; Barbosa, A. A.; Blanco, B. A. Sífilis congênita e gestacional: diagnóstico e tratamento. Revista Saúde em Foco, no. 9, p. 103-119, 2017. Available from: <http://unifia.edu.br/ revista_eletronica/revistas/saude_foco/artig os/ano2017/012_sifilis_congenita.pdf>.

Accessed on: Jun. 26, 2018.

Silva, V.S.T. Os (des)caminhos da sífilis congênita no Município de Botucatu, São Paulo. Botucatu: Universidade Estadual Paulista, 2016. (Dissertation). Available from: <http://hdl.handle.net/11449/138179>.

Accessed on: Jun. 26, 2018.

WHO - World Health Organization. Eliminação mundial da sífilis congênita: fundamento lógico e estratégia para ação. Genebra: WHO, 2008. Available from: <http://apps.who.int/iris/bitstream/10665/ 43782/4/9789248595851_por.pdf>. Accessed on: Jun. 26, 2018. 